\title{
Hubungan Pola Makan dan Pola Menstruasi Remaja Putri MA Athoriyah Kecamatan Cikatomas Kabupaten Tasikmalaya Tahun 2016
}

\author{
Meti Megawati,S.KM,M.Kes \\ (meti.megawati81@gmail.com)
}

\section{A. Abstrak}

Hasil studi pendahuluan diperoleh data sekunder dari laporan tahunan Program Kesehatan Keluarga Dinas Kesehatan Kabupaten Tasikmalaya, dalam kurun waktu 4 tahun terakhir terjadi peningkatan angka kejadian anemia pada remaja putri. Data terakhir Tahun 2013,yaitu jumlah anemia tertinggi sebanyak 24 orang (40\%) dari 60 orang siswi, terdapat di Sekolah MA Athoriyah Cikatomas dan SMA Serba Bakti Suryalaya Pagerageung. Tujuan penelitian ini untuk mengetahui hubungan pola makan dan pola menstruasi dengan kejadian anemia pada remaja putri di MA Athoriyah Kecamatan Cikatomas Kabupaten Tasikmalaya Tahun 2016. Manfaat penelitian ini berkontribusi dalam keilmuan Gizi masyarakat dan Ilmu Perilaku dan menjadi dasar dalam penyusunan program perencanaan kegiatan pencegahan dan penanggulangan anemia pada remaja.

Jenis penelitian ini kuantitatif dengan metode analitik, dan rancangan cross sectional. Populasi adalah seluruh siswi putri pada Athoriyah Cikatomas kelas X dan XI. Sampel diambil dengan teknik Total Sampling, yaitu sebanyak 41 orang. Instumen menggunakan kuesioner sebanyak 10 soal. Data diuji menggunakan analisis univariat dan bivariat dengan uji Chi-Square.

Hasil penelitian diperoleh hubungan antara pola makan dengan kejadian anemia $(p=$ 0,005), nilai $O R=17,600$, artinya remaja putri dengan pola makan kurang baik memiliki peluang 17,6 kali mengalami anemia dibandingkan dengan remaja putri yang pola makannya baik. Serta ada hubungan pola menstruasi dengan kejadian anemia $(p=0,031)$, nilai $O R=7,733$, artinya remaja putri dengan pola menstruasi beresiko memiliki peluang 7,733 kali mengalami anemia dibandingkan dengan remaja putri yang pola menstruasinya tidak beresiko.

Diharapkan remaja putri memperbaiki perilaku hidup sehat, diantaranya: merubah pola makan yang sehat dan berkualitas, mencegah anemia pada saat terjadi menstruasi dengan mengkonsumsi tablet tambah darah, dan mencari informasi terkait penanggulangan anemia untuk mempersiapkan kesehatan reproduksinya menjelang pernikahan dan proses kehamilan. Adapun bagi sekolah dan tenaga kesehatan lebih intensif memberikan pendidikan kesehatan/penyuluhan tentang gizi dan anemia kepada remaja putri, melakukan pemeriksaan rutin kadar Hb dan pemberian tablet tambah darah (TTD) dan asam folat.

\section{Kata Kunci: Anemia, Pola Makan, Pola Menstruasi}




\section{B. Latar Belakang}

Remaja putri dan calon pengantin harus membiasakan mengkonsumsi aneka ragam makanan untuk memenuhi kebutuhan energi, protein dan zat mikro (vitamin dan mineral) karena digunakan untuk pertumbuhan yang cepat, peningkatan volume darah dan peningkatan haemoglobin. Zat mikro penting yang dibutuhkan pada remaja putri adalah zat besi dan asam folat. Kebutuhan zat besi bagi remaja putri dan calon pengantin diperlukan untuk membentuk haemoglobin yang mengalami peningkatan dan mencegah anemia yang disebabkan karena kehilangan zat besi selama menstruasi (Kemenkes, 2014).

Data Riskesdas (2013) menunjukkan secara Nasional prevalensi anemia gizi pada kelompok usia remaja (15-24 tahun) sebesar 18,4\%. Selain itu, tingginya angka pernikahan dini/remaja (48\%) menyumbangkan dampak yang tinggi terhadap kejadian anemia yang merupakan implikasi kehamilan dari remaja yang anemia yaitu sebanyak 48 per 1000 kehamilan. Kehamilan dengan anemia ini akan berdampak pada kematian ibu yang diakibatkan oleh perdarahan pada saat persalinan.

Beberapa penelitian yang dilakukan di SMA oleh Puspitasari, dan Listiowati, begitupun Handayani, Novayelinda dan Jumaini, rata-rata siswi yang dilakukan pemeriksaan kadar $\mathrm{Hb}$ ada dalam keadaan anemia. Berikut hasil penelitian Budiman (1997), remaja putri SMU dan MAN di enam daerah Kabupaten di Jawa Barat menunjukkan prevalensi anemia sebesar 41,54\%. Diperoleh beberapa faktor yang berhubungan dengan kejadian anemia pada remaja putri, yaitu asupan energi, protein, zat besi, Vitamin $\mathrm{C}$, kebiasaan minum teh atau kopi, investasi cacing, pengetahuan, pendidikan dan jenis pekerjaan orangtua, pendapatan keluarga dan pola menstruasi.
Menyadari hal tersebut, agar kelak mempunyai keturunan yang sehat dan ibu melahirkan dengan selamat, maka setiap pasangan perlu perencanaan dalam kehamilan. Upaya meningkatkan derajat kesehatan ibu harus dilaksanakan secara komprehensif. Intervensi program kesehatan ibu, tidak bisa hanya dilakukan di bagian hilir saja, yaitu pada ibu hamil, namun juga perlu ditarik ke hulu, yaitu pada kelompok remaja dan dewasa muda untuk memastikan individu dapat tumbuh dan berkembang secara sehat dalam mempersiapkan diri pada saat kehamilan dan sepanjang siklus reproduksinya.

Berdasarkan studi pendahuluan diperoleh data sekunder dari laporan tahunan Program Kesehatan Keluarga Dinas Kesehatan Kabupaten Tasikmalaya, menunjukkan dalam kurun periode waktu 4 tahun terakhir terjadi peningkatan angka kejadian anemia pada remaja putri, yang berkunjung dan terjaring oleh pemeriksaan hemolglobin pada 40 Puskesmas di 39 Kecamatan Kabupaten Tasikmalaya, yaitu: 1) sebanyak 178 remaja putri pada tahun 2012 ; 2) sebanyak 77 orang pada tahun 2013 ; 3) sebanyak 65 orang pada tahun 2014, serta terjadi peningkatan drastis pada tahun 2015, yaitu sebanyak 155 orang.

Sedangkan data terakhir Rekapitulasi Cakupan Penderita Anemia pada Pemeriksaan $\mathrm{Hb}$ Terhadap Anak Sekolah Tahun 2013 yang dilaksanakan oleh Dinas Kesehatan Kabupaten Tasikmalaya, diperoleh hasil pemeriksaan dengan jumlah anemia tertinggi sebanyak 24 orang $(40 \%)$ dari 60 orang siswi, terdapat di Sekolah MA Athariyah Cikatomas dan SMA Serba Bakti Suryalaya Pagerageung.

Menurut penelitian Nursari (2010), terdapat faktor-faktor penyebab yang mempengaruhi kejadian anemia antara lain asupan zat gizi, perilaku makan dan 
minum, kehilangan darah, sosial ekonomi, dan status gizi. Anemia gizi besi (AGB) merupakan masalah gizi mikro yang paling banyak terjadi di dunia. Menurut WHO (2008), dari total kasus anemia, 50\% disebabkan oleh kekurangan zat besi. Remaja putri merupakan kelompok yang rentan menderita anemia dibandingkan remaja putra. Defisiensi besi meningkat pada remaja putri dikarenakan oleh perdarahan pada saat menstruasi dan dalam waktu yang bersamaan kadar hemoglobin menurun. Selain itu remaja merupakan periode terjadinya pertumbuhan pesat kedua setelah bayi (Brown, 2011).

Tujuan penelitian ini adalah untuk mengetahui hubungan pola makan dan pola menstruasi dengan kejadian anemia pada remaja putri di MA Athoriyah Kecamatan Cikatomas Kabupaten Tasikmalaya tahun 2016.

\section{Metode}

Penelitian ini adalah kuantitatif menggunakan metode analitik dengan rancangan cross sectional, yaitu untuk menganalisis faktor risiko pola makan, pola menstruasi, dan kejadian anemia pada remaja putri MA Athoriyah Cikatomas.

Populasi penelitian ini adalah seluruh remaja putri pada MA Athoriyah Cikatomas kelas X dan XI pada tahun ajaran 2015-2016, yaitu sebanyak 73 orang.

Besar sampel pada penelitian ini diambil secara total sampling dari populasi dikarenakan jumlah populasi relatif sedikit (< 100 orang). Dari seluruh jumlah populasi, hanya 41 orang yang bersedia dijadikan responden.

Instrumen yang digunakan untuk penelitian ini adalah menggunakan kuesioner sebanyak 11 soal. Kuesioner ini telah diuji validitas di MA Darul Abror Kecamatan Cisayong, diambil sampel minimal yaitu sebanyak 20 orang remaja putri dari kelas X dan XI yang mempunyai karakteristik objek dan tempat yang sama dengan MA Athoriyah Kecamatan Cikatomas. Diperoleh hasil $r$ hitung $>\mathrm{r}$ table $(\mathrm{r}$ hitung 0,93 dan $\mathrm{r}$ table $=0,44$ ) dan sehingga diperoleh soal yang valid dan reliable sebanyak 10 soal.

Selain itu penelitian ini memerlukan alat untuk melakukan pemeriksaan kadar hemoglobin yaitu dengan menggunakan Hemoglobinometer Easytouch. Pengambilan data dilaksanakan dengan memberikan kuesioner kepada responden dan melakukan pemeriksaan $\mathrm{Hb}$ dengan teknik Finger Prick yang dianalisis menggunakan Hemoglobinometer Easytouch.

Selain itu, diperoleh data sekunder melalui studi dokumentasi, wawancara dengan petugas kesehatan dan pemegang program di Dinas Kesehatan Kabupaten, DTP Puskemas UPTD Cikatomas, dan Kepala Sekolah MA Athoriyah Kecamatan Cikatomas.

Analisis data menggunakan analisis univariat untuk menghasilkan distribusi frekuensi dan presentase dari tiap vaariabel. Sedangkan untuk menguji hipotesa dan melihat gambaran hubungan pola makan dan pola menstruasi dengan kejadian anemia pada remaja putri maka dapat dibuat dalam bentuk table silang. Uji statistik yang digunakan sesuai dengan skala yang dipakai, yaitu uji Chi- Square. Proses analisis data dibantu dengan menggunakan program komputerisasi. Hasil analisis data yang diperoleh, yaitu suatu hipotesa (Ho) ditolak apabila nilai $\alpha<$ p-value, yaitu derajat kesalahan yang bernilai 0,05 (Sugiyono, 2007). 


\section{Hasil penelitian}

1. Kejadian Anemia

Tabel 1. Distribusi Frekuensi Kejadian Anemia Remaja Putri di

MAN At-Thoriyah Kecamatan Cikatomas Kabupaten Tasikmalaya Tahun 2016

\begin{tabular}{|c|c|c|}
\hline $\begin{array}{c}\text { Kejadian } \\
\text { Anemia }\end{array}$ & $\begin{array}{c}\text { Frekuensi } \\
\text { (f) }\end{array}$ & $\begin{array}{c}\text { Persentase } \\
(\%)\end{array}$ \\
\hline $\begin{array}{c}\text { Tidak } \\
\text { Anemia }\end{array}$ & 9 & 22 \\
\hline Anemia & 32 & 78 \\
\hline $\begin{array}{c}\text { Jumlah } \\
\text { Total (N) }\end{array}$ & 41 & 100 \\
\hline
\end{tabular}

Berdasarkan tabel 1. dapat dilihat bahwa dari 41 responden, sebagian besar mengalami anemia, yaitu sebanyak 32 orang $(78 \%)$.

2. Pola Makan

Tabel 2. Distribusi Frekuensi Pola Makan Remaja Putri di MAN At-Thoriyah Kecamatan Cikatomas Kabupaten Tasikmalaya Tahun 2016

\begin{tabular}{|c|c|c|}
\hline $\begin{array}{c}\text { Pola } \\
\text { Makan }\end{array}$ & $\begin{array}{c}\text { Frekuensi } \\
\text { (f) }\end{array}$ & $\begin{array}{c}\text { Persentase } \\
(\%)\end{array}$ \\
\hline Baik & 18 & 56,1 \\
\hline Kurang & 23 & 43,9 \\
\hline $\begin{array}{c}\text { Jumlah } \\
\text { Total (N) }\end{array}$ & 41 & 100 \\
\hline
\end{tabular}

Berdasarkan tabel 2. dapat dilihat bahwa dari 41 orang responden, sebagian besar mempunyai pola makan kurang baik, yaitu sebanyak 23 orang (43,9\%). 
3. Pola Menstruasi

Tabel 3. Distribusi Frekuensi Pola Menstruasi Remaja Putri

Di MAN At-Thoriyah Kecamatan Cikatomas Kabupaten Tasikmalaya

Tahun 2016

\begin{tabular}{|c|c|c|}
\hline Pola Menstruasi & $\begin{array}{c}\text { Frekuensi } \\
\text { (f) }\end{array}$ & Persentase (\%) \\
\hline $\begin{array}{c}\text { Tidak Beresiko } \\
\text { Anemia }\end{array}$ & 23 & 56,1 \\
\hline Beresiko Anemia & 18 & 43,9 \\
\hline Jumlah Total (N) & 41 & 100 \\
\hline
\end{tabular}

Berdasarkan tabel 3. dapat dilihat bahwa dari 41 orang responden, sebagian besar mempunyai pola menstruasi yang beresiko anemia, yaitu 23 orang (43,9\%).Pengetahuan tentang Anemia Remaja Putri di MAN At-Thoriyah.

4. Pola Makan dan Kejadian Anemia

Tabel 4. Distribusi Remaja Putri Berdasarkan Pola Makan dan Kejadian Anemia di MAN At-Thoriyah Kecamatan Cikatomas

Kabupaten Tasikmalaya Tahun 2016

\begin{tabular}{|c|c|c|c|c|c|c|c|c|}
\hline \multirow{3}{*}{$\begin{array}{c}\text { Pola } \\
\text { Makan }\end{array}$} & \multicolumn{4}{|c|}{ Kejadian Anemia } & \multirow{2}{*}{\multicolumn{2}{|c|}{ Total }} & \multirow{3}{*}{$\begin{array}{c}\text { OR } \\
(95 \% \mathrm{CI})\end{array}$} & \multirow[t]{3}{*}{ P Value } \\
\hline & \multicolumn{2}{|c|}{ Tidak Anemia } & \multicolumn{2}{|c|}{ Anemia } & & & & \\
\hline & $\mathrm{N}$ & $\%$ & $\mathrm{n}$ & $\%$ & $\mathrm{~N}$ & $\%$ & & \\
\hline Baik & 8 & $88,9 \%$ & 10 & $31,2 \%$ & 18 & 34,9 & 17,600 & 0,005 \\
\hline Kurang & 1 & $11,1 \%$ & 22 & $68,8 \%$ & 23 & 56,1 & $1,932-160,302$ & \\
\hline Jumlah & 9 & 100 & 32 & 100 & 41 & 100 & & \\
\hline
\end{tabular}

Hasil tabulasi silang antara pola makan dan kejadian anemia diperoleh bahwa sebanyak 22 orang $(68,6 \%)$ remaja putri dengan pola makan kurang mempunyai status anemia. Sedangkan remaja putri yang memiliki pola makan baik sebanyak 8 orang $(31,2 \%)$ tidak mengalami anemia. Hasil uji statistik diperoleh nilai $p=0,005$ maka dapat disimpulkan ada hubungan yang signifikan antara pola makan dengan kejadian anemia. Hasil analisis diperoleh pula nilai $\mathrm{OR}=17,600$, artinya remaja putri dengan pola makan kurang baik memiliki peluang 17,6 kali mengalami anemia dibandingkan dengan remaja putri yang pola makannya baik. 
5. Pola Menstruasi dan Kejadian Anemia

Tabel 5. Distribusi Remaja Putri Berdasarkan Pola Menstruasi dan Kejadian Anemia di MAN At-Thoriyah Kecamatan Cikatomas

Kabupaten Tasikmalaya Tahun 2016

\begin{tabular}{|c|c|c|c|c|c|c|c|c|}
\hline \multirow[t]{3}{*}{ Pola Menstruasi } & \multicolumn{4}{|c|}{ Kejadian Anemia } & \multirow{2}{*}{\multicolumn{2}{|c|}{ Total }} & \multirow{3}{*}{$\begin{array}{c}\text { OR } \\
(95 \% \mathrm{CI})\end{array}$} & \multirow[t]{3}{*}{ P Value } \\
\hline & \multicolumn{2}{|c|}{ Tidak Anemia } & \multicolumn{2}{|c|}{ Anemia } & & & & \\
\hline & $\mathrm{N}$ & $\%$ & $\mathrm{n}$ & $\%$ & $\mathrm{~N}$ & $\%$ & & \\
\hline Tidak Beresiko & 4 & $44,4 \%$ & 3 & $9,4 \%$ & 18 & 34,9 & 7,733 & 0,031 \\
\hline Beresiko & 5 & $55,5 \%$ & 29 & $90,6 \%$ & 23 & 56,1 & $1,314-1,314$ & \\
\hline Jumlah & 9 & 100 & 32 & 100 & 41 & 100 & & \\
\hline
\end{tabular}

a

sil tabulasi silang antara pola menstruasi dan kejadian anemia diperoleh bahwa sebanyak 29 orang $(90,6 \%)$ remaja putri dengan pola menstruasi beresiko mengalami kejadian anemia. Sedangkan remaja putri yang memiliki pola menstruasi tidak beresiko anemia sebanyak 4 orang $(44,4 \%)$ tidak mengalami kejadian anemia. Hasil uji statistik diperoleh nilai $\mathrm{p}=0,031$ maka dapat disimpulkan ada hubungan yang signifikan antara pola menstruasi dengan kejadian anemia. Hasil analisis diperoleh pula nilai $\mathrm{OR}=7,733$, artinya remaja putri dengan pola menstruasi beresiko memiliki peluang 7,733 kali mengalami anemia dibandingkan dengan remaja putri yang pola menstruasinya tidak beresiko 


\section{E. Pembahasan}

Berdasarkan hasil penelitian diperoleh data bahwa dari 41 responden, sebagian besar mengalami anemia, yaitu sebanyak 32 orang $(78 \%)$ dan 9 orang $(22 \%)$ tidak mengalami anemia.hasil penelitian didapatkan sebanyak 23 orang $(43,9 \%)$, diantaranya sebagian besar remaja putri yang memiliki pola makan kurang baik, yaitu sebanyak 23 orang $(43,9 \%)$, dan pola menstruasi yang beresiko anemia, yaitu sebanyak 23 orang $(43,9 \%)$.

Pola makan yang baik bagi remaja putri adalah cukup kuantitas dan berkualitas sehingga akan mempengaruhi kesehatan. Gizi yang optimal sangat penting untuk pertumbuhan normal serta perkembangan fisik dan kecerdasan. Gizi baik membuat berat badan normal atau sehat, tubuh tidak mudah terkena penyakit infeksi, produktivitas kerja meningkat serta terlindung dari penyakit kronis dan kematian dini. Agar tubuh tetap sehat dan terhindar dari berbagai penyakit kronis atau penyakit tidak menular terkait gizi, maka pola makan masyarakat perlu ditingkatkan kearah konsumsi gizi seimbang (Kemenkes, 2014).

Pola dan gaya hidup modern membuat remaja cenderung lebih menyukai makan di luar rumah bersama kelompoknya. Remaja putri sering mempraktikkan diet dengan cara yang kurang benar seperti melakukan pantangan-pantangan, membatasi atau mengurangi frekuensi makan untuk mencegah kegemukan. Pada umumnya remaja mempunyai kebiasaan makan yang kurang baik. Beberapa remaja khususnya remaja putri sering mengkonsumsi makanan dalam jumlah yang tidak seimbang dibandingkan dengan kebutuhannya karena takut kegemukan dan menyebut makan bukan hanya dalam konteks mengkonsumsi makanan pokok saja tetapi makanan ringan juga dikategorikan sebagai makan (Arisman, 2004).
Hal ini sesuai dengan penelitian Sabarina di Banda Aceh tahun 2013 yang menyatakan bahwa rata-rata penderita anemia pada remaja putri yang memiliki pola makan yang kurang baik.

Selain pola makan, salah satu penyebab anemia gizi pada remaja putri adalah kehilangan darah secara kronis melalui kehilangan darah yang terjadi secara alamiah setiap bulan melalui menstruasi. Jika darah yang keluar selama menstruasi sangat banyak maka akan terjadi anemia defisiensi besi (Arisman, 2004).

Hasil uji statistik didapatkan nilai $\mathrm{p}=0,005$ maka dapat disimpulkan ada hubungan yang signifikan antara pola makan dengan kejadian anemia. Hasil analisis diperoleh pula nilai $\mathrm{OR}=17,600$, artinya remaja putri dengan pola makan kurang baik memiliki peluang 17,6 kali mengalami anemia dibandingkan dengan remaja putri yang pola makannya baik.

Hal ini sesuai dengan pola gizi seimbang untuk remaja usia 10-19 tahun (Pra-pubertas dan Pubertas) bahwa pola makan berpengaruh terhadap pemenuhan kebutuhan zat gizi kelompok ini, yaitu untuk pertumbuhan cepat memasuki usia pubertas. Begitu pula dengan kondisi penting remaja, yaitu kebiasaan jajan, menstruasi dan perhatian terhadap penampilan fisik citra tubuh (body image) pada remaja puteri. Dengan demikian perhitungan terhadap kebutuhan zat gizi pada kelompok ini harus memperhatikan kondisi-kondisi tersebut. Khusus pada remaja puteri, perhatian harus lebih ditekankan terhadap persiapan mereka sebelum menikah (Kemenkes, 2014).

Secara umum anak usia 10-19 tahun telah memasuki masa remaja yang mempunyai karakteristik motorik dan kognitif yang lebih dewasa dibanding usia sebelumnya. Hal ini berdampak pada pentingnya kebutuhan energi, protein, lemak, air, kalsium, magnesium, vitamin D dan vitamin A yang penting bagi pertumbuhan. Perilaku pola makan remaja putri, yaitu meliputi frekuensi makan $<2$ kali, keanekaragaman makanan meliputi 
kurang konsumsi makanan hewani, nabati, sayuran dan buah-buahan, serta jenis minuman yang dikonsumsi yaitu minum kopi $>3$ cangkir dalam seminggu.

Kebutuhan gizi remaja relatif besar, karena mereka masih mengalami pertumbuhan. Selain itu, remaja umumnya melakukan aktifitas fisik lebih tinggi dibanding usia lainnya, sehingga diperlukan zat gizi yang lebih banyak. Akan tetapi kenyataannya kebanyakan remaja umumnya menginginkan bentuk tubuh yang ideal, sampai rela diet ketat untuk menurunkan berat badannya, hal ini menyebabkan remaja putri membatasi pola makannya. Pola makan yang kurang baik akan menyebabkan anemia karena makanan berfungsi untuk memelihara kesehatan tubuh melalui manfaat zat-zat gizi yang terkandung di dalamnya.

Hal ini sesuai dengan penelitian Hapzah dan Yulita (2012), bahwa kejadian anemia remaja putri sebesar 42,2 \%. Variabel kebiasaan diet dan kejadian anemia berhubungan secara bermakna dengan nila $\mathrm{p}$ value $<\alpha \quad 0,05$. Hasil penelitian yang lain oleh Permaesih dan dan Herman (2005), diperoleh kebiasaan sarapan pagi berhubungan secara bermakna dengan terjadinya anemia $(p<0,05)$. Presentase anemia responden yang tidak sarapan pagi lebih besar, yaitu 34,5\% daripada yang sarapan pagi. Gambaran OR menunjukkan responden yang tidak biasa sarapan pagi berisiko menderita anemia 0,6 kali $(\mathrm{OR}=0,6 ; 95 \%$ CI 0,4-0,9).

Hasil uji statistik diperoleh nilai $\mathrm{p}=0,031$ maka dapat disimpulkan ada hubungan yang signifikan antara pola menstruasi dengan kejadian anemia. Hasil analisis diperoleh pula nilai $\mathrm{OR}=7,733$, artinya remaja putri dengan pola menstruasi beresiko memiliki peluang 7,733 kali mengalami anemia dibandingkan dengan remaja putri yang pola menstruasinya tidak beresiko.

Hal ini sesuai dengan teori bahwa setiap wanita mempunyai siklus menstruasi yang berlainan, normalnya dalam satu siklus kurang lebih setiap 28 hari, bisa berfluktuasi 7 hari dan total kehilangan darah antara 60 sampai $250 \mathrm{~mm}$ (Anonymous, 2013). Haid yang dialami setiap wanita sangat bervariasi dan beranekaragam, salah satunya adalah seorang wanita yang mengalami haid lebih dari 7 hari dan darah yang keluar lebih banyak tidak seperti biasanya (Tardiana, 2012).

Salah satu faktor pemicu anemia adalah kondisi siklus menstruasi yang tidak normal. Kehilangan banyak darah saat menstruasi diduga dapat menyebabkan anemia (Niken, 2013). Kehilangan darah yang sebenarnya apabila mengalami kadar menstruasi yang berlebihan lebih dari 3-4 hari. Pembalut atau tampon selalu basah setiap jamnya dan sering menggantinya. Jika hal ini terjadi lebih dari 3 hari, maka segera kunjungi dokter, dan kalau pada saat menstruasi terlihat pucat atau merasa mau pingsan jangan tunggu sampai tiga hari (Megabohari,2011).

Hasil penelitian ini sejalan dengan penelitian Prastika (2011) diperoleh hasil $\mathrm{r}$ hitung $=0,624$ dan $\mathrm{p}=0,000 \quad(\mathrm{p}<0,05)$, terdapat hubungan antara siklus menstruasi (22-35 hari) dan lama menstruasi $>6$ hari dengan kejadian anemia. Artinya semakin lama menstruasi maka akan semakin rendah kadar hemoglobin

Diharapkan kepada sekolah bersama puskesmas dapat bersama-sama untuk memberikan penyuluhan/pendidikan kesehatan tentang gizi seimbang pada remaja, kesehatan reproduksi, pemberian asam folat dan tablet tambah darah pada saat menstruasi untuk membantu pembentukan hemoglobin pada sel darah merah. 


\section{F. Simpulan dan saran}

Berdasarkan penelitian yang telah dilakukan terhadap 41 orang remaja putri di MA At-Thariyah Kecamatan Cikatomas Kabupaten Tasikmalaya, maka dapat disimpulkan bahwa:

1. Sebagian besar responden mengalami anemia, yaitu sebanyak 32 orang $(78 \%)$.

2. Sebagian besar responden mempunyai pola makan kurang baik, yaitu sebanyak 23 orang $(43,9 \%)$.

3. Sebagian besar responden mempunyai pola menstruasi yang beresiko anemia, yaitu sebanyak 34 orang $(82,9 \%)$.

4. Ada hubungan yang signifikan antara pola makan dengan kejadian anemia $(p=0,005)$ pada remaja putri di MA At-Thariyah Kecamatan Cikatomas Kabupaten Tasikmalaya.

5. Ada hubungan yang signifikan antara pola menstruasi dengan kejadian anemia $(\mathrm{p}=0,031)$ pada remaja putri di MA At-Thariyah Kecamatan Cikatomas Kabupaten Tasikmalaya.

Diharapkan remaja putri memperbaiki perilaku hidup sehat, diantaranya: merubah pola makan yang sehat dan berkualitas, mencegah anemia pada saat terjadi menstruasi dengan mengkonsumsi tablet tambah darah, dan mencari informasi terkait penanggulangan anemia untuk mempersiapkan kesehatan reproduksinya menjelang pernikahan dan proses kehamilan.

Sedangkan bagi sekolah MA AtThariyah dapat dan Puskesmas setempat lebih intensif memberikan pendidikan kesehatan/penyuluhan tentang anemia kepada remaja putri, dan melakukan pemeriksaan rutin kadar hemoglobin, bekerjasama dengan tenaga kesehatan atau instansi pelayanan kesehatan setempat.

\section{G. Referensi}

Almatsier, Sunita. (2001). Prinsip Dasar Ilmu Gizi, Penerbit PT. Gramedia Pustaka Utama, Jakarta.

Arikunto, Suharsimi. (2006). Prosedur Penelitian Suatu Pendekatan Praktek, Penerbit Rineka Cipta, Jakarta.

Arisman. (2004). Gizi dalam Daur Kehidupan, Penerbit Buku Kedokteran EGC, Jakarta.

Arumsari, E. (2008). Faktor Risiko Anemia pada Remaja Putri Peserta Program Pencegahan dan Penanggulanagn Anemia Gizi Besi (PPAGB) Di Kota Bekasi, Skripsi Fakultas Pertanian Institut Pertanian Bogor, Bogor.

Anonymaous. (2013) Perdarahan Berlebih Saat Menstruasi. Dalam situs URL:http://WanitaDuniaWanita/Perdarahan/Berlebih/Sa at/Menstruasi. Diakses $5 \mathrm{Mei}$ 2016.

Husaini, dkk. (1989). Nutritional Anemia An Assesment of Information Compilation for Supporting and Formulating National Policy and Program, Direktorat Bina Gizi Masyarakat dan Pusat Penelitian dan Pengembangan Gizi, Depkes RI, Jakarta.

Kemenkes RI. (2014). Peraturan Menteri Kesehatan Republik Indonesia Nomor 41 Tahun 2014 Tentang Pedoman Gizi Seimbang, Kementerian Kesehatan Republik Indonesia, Jakarta.

Megabohari. (2011). Anemia Saat Menstruasi. Dalam situs 
URL:http://megabohari@yahoo .com. Diakses 14 April 2016

Niken. (2013). Menstruasi Tidak Normal, Waspada Anemia. Dalam situs URL:http://okehealth/detailheal thupdate/29/03/2013). Diakses 14 April 2016

Notoatmodjo, Soekidjo. (2005). Metodologi Penelitian

Kesehatan, Penerbit Rineka Cipta, Jakarta.

Nursyahidah, Imran. (2014). Pengetahuan Dan Sikap Tentang Anemia Dengan Status Hemoglobin Remaja Putri Di SMA Negeri 10 Makasar, Bagian Ilmu Gizi Fakultas Kesehatan Masyarakat Universitas Hasanudin, Makasar.

Permaesih, dkk. (2005). Faktorfaktor Yang Mempengaruhi Anemia pada Remaja, Buletin Penelitian Kesehatan, Volume 33, No.4, 2005:162-171, Jakarta.

Proverawati. (2011). Anemia dan Anemia Kehamilan, Penerbit Nuha Medika, Yogyakarta.

Puspitasari, Listiowati (2013). Hubungan Tingkat Pengetahuan dan Perilaku tentang Gizi terhadap Kejadian Anemia pada Remaja Putri, Fakultas Kedokteran dan Ilmu Kesehatan UMY: Yogyakarta.

Sadikin. (2001). Biokimia Darah, Penerbit Widya Medika, Jakarta.

Sediaoetomo. (2006). Ilmu Gizi untuk Mahasiswa dan Profesi, Penerbit Dian Rakyat, Jakarta.

Supariasa, dkk. (2002) Penilaian Status Gizi, Penerbit Buku Kedokteran EGC, Jakarta. Stang, Jamie. and Story, Mary. (2005). Guidelines for Adolescent Nutriton Services. Center for Leadership,
Education, and Training in Maternal and Child Nutrition, Division of Epidemiology and Community Health, School of Public Health, University of Minnesota.

Suryani, Hafiani dan Junita (2016). Analisis Pola MAkan dan Anemia Gizi Besi pada Remaja Putri Kota Bengkulu, Jurnal Kesehatan Masyarakat Andalas, Volume 10, No.1, 2016: 11-18, Bengkulu.

Tardiana, Ana. (2012). Haid Tidak Berhenti Dan Banyak Mengeluarkan Darah. Dalam situs URL:http://anatardiana.blogspot.com/diberday akan.oleh.bloger. Diakses 5 Mei 2016.

World Health Organization. (2001). Iron deficiency, anemia, prevention, and control, $A$ guide for programme managers, WHO, Geneva.

World Health Organization. (2008). Wolrdwide Prevalence of Anemia 1993-2005, WHO Global Database on Anaemia, WHO, Geneva.

Wirakusumah E.S. (2010). Sehat Cara Al-Qur'an dan Hadits, Penerbit Hikmah, Jakarta.

Zen. (2013). Penyebab Anemia dan Faktor Resikonya. Dalam situs URL:http://zonakesehatan.word press.com/2013/01/17/penyeba b-anemia-dan-faktor-resikonya. Diakses 5 Mei 2016 